\title{
Is the relationship between pharma and medical education on the rocks?
}

\author{
How much longer will medicine's flagship educational events fly the colours of the \\ drug industry, asks Ray Moynihan
}

n $\mathrm{n}$ the heart of Manhattan Island one misty morning a few years back, I watched as hundreds of psychiatrists streamed into their flagship educational event, the annual congress. ${ }^{1}$ Even before arriving they were welcomed by giant advertising billboards on the streets outside, plastered with the name of a major sponsor, Pfizer, the biggest drug company in the world and the maker of Zoloft, the world's top selling antidepressant. Once inside, their first port of call was the huge exhibition hall, where well dressed salespeople moved among the high tech booths and hypnotic neon, exchanging pleasantries with doctors lining up to play video games and win prizes. And then, of course, there were the sponsored educational sessions. That year-2004-psychiatrists learnt about bipolar disorder over breakfast at the Marriott Marquis Hotel, courtesy of Eli Lilly. Over lunch at the Grand Hyatt they studied maternal depression, thanks to GlaxoSmithKline, and for dinner it was generalised anxiety disorder in the grand ballroom of the Roosevelt Hotel, funded by Pfizer.

Although the educational flagships of many medical specialties proudly fly the colours of their drug company sponsors, psychiatry has long been suspected as being most entangled with industry; a suspicion that is confirmed by the world's nascent disclosure regimes. In the small northeastern state of Vermont, where drug makers must now disclose payments to doctors, psychiatrists are the biggest recipients. ${ }^{2}$ In
Australia, where the courts have forced the industry to disclose the details of every sponsored event, psychiatrists are "educated" with industry's hospitality more often than any other subspecialty. ${ }^{3}$

\section{Growing anxiety}

Increasingly anxious about the industry's influence over their education a small group of psychiatrists in Australia has tried to wind back drug company sponsorship of their annual congress. Two years ago Malcolm Battersby, an associate professor of psychiatry at Flinders University in Adelaide, became convenor of a small organising committee that was charged with planning the 2009 congress of the Royal Australian and New Zealand College of Psychiatrists. Battersby practises at his associated teaching hospital, the Flinders Medical Centre, and is a former Harkness fellow in health policy. His organising committee's key reform proposal was a modest one: they wanted to remove the rights to the naming of the congress from drug companies, replacing the lost income with sponsorship from public or not for profit sources. "To me the congress is the symbol of psychiatry in the community, it's our official public event, yet here we are parading ourselves arm in arm with drug companies," says Battersby. At the 2008 congress, for which psychiatrists earn continuing professional development points by the hour, every major sponsor was a marketer of drugs. "This has the appearance of a marriage and the overt message to the community is "we are drugs," said Battersby. Apart from the problem of appearances, Battersby and his colleagues are concerned that patients are being harmed. "Psychiatrists are unwittingly influenced by pharmaceutical sponsorship of education, and the consequence is inappropriate prescribing and the harms that might arise," he said.

\section{Fundamentally incompatible}

Although more than half of continuing education is sponsored by drug and device makers, ${ }^{4}$ good evidence about the effects of sponsorship is sparse. What evidence there is suggests that drug companies use accredited continuing medical education as part of marketing campaigns. Sponsors' drugs can receive favourable treatment, and irrational prescribing may result. ${ }^{5}$ Notwithstanding the uncertainty in the evidence, calls for disentanglement are increasing. A special task force from the Association of American Medical Schools is demanding more separation between sponsors and ${ }^{7}$ a recent report from the Josiah Macy Foundation recommends a comprehensive ban on direct and indirect sponsorship of continuing education. ${ }^{4}$

On the basis of a meeting of experts which she chaired for the Josiah Macy Foundation, Harvard professor Suzanne Fletcher writes that the responsibilities of for profit companies and health professionals were "fundamentally incompatible" and that bias "has become woven into the very fabric of continuing education." " Moreover, according to Fletcher's report, "no amount of strengthening of the 'firewall' between commercial entities and the content and processes of continuing education can eliminate the potential for bias." Her report went on to recommend a five year "phase-out" of all support from drug or medical device companies. 


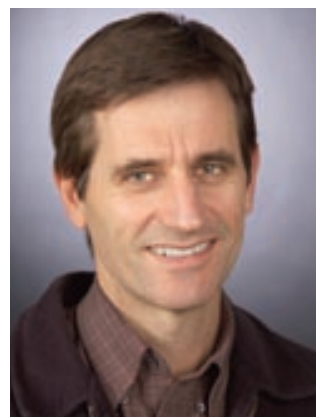

\section{Psychiatrists are unwittingly influenced by pharmaceutical sponsorship of education}

Malcolm Battersby

At about the same time as Fletcher's recommendations were being prepared, a split was brewing in Australian psychiatry over the issue of industry's sponsorship of its congress and its education. As Malcolm Battersby and his colleagues pushed ahead with their plans to seek non-drug sponsors for the naming rights at the 2009 congress, they won support from the South Australian branch of the national college. Importantly, the organising committee had also begun securing non-commercial sponsors to pay for the naming rights for the congress. But in April 2008, the federal council of the college met and decided to reject the reform plan, arguing that it was not in line with college policy to discriminate against or in favour of particular categories of sponsors. Battersby and some of his colleagues on the organising committee for the 2009 congress, including psychiatrist Jon Jureidini, resigned en masse from the organising committee.

"In my opinion the college got freaked by the possible consequences of offending the pharmaceutical industry-and it struggled to find a rationalisation for not allowing that to happen," says Jureidini, senior child psychiatrist, associate professor at the University of Adelaide and chair of Healthy Skepticism, an advocacy group calling for an end to industry funded education. "There is good evidence this is bad for our patients, because doctors become too fond of pharmaceuticals and use them more indiscriminately. We are well remunerated and can afford to pay for our own education." Accepting that they may have lost the battle over sponsorship of the 2009 congress, the reformers are continuing their push for disengagement from industry. Battersby is getting involved with the college's continuing medical education committee, and Jureidini has joined the ethics committee.

\section{Reviewing the relationship}

The annual congress is the "flagship educational event of the year," says Ken Kirkby, the president of the Royal Australian and
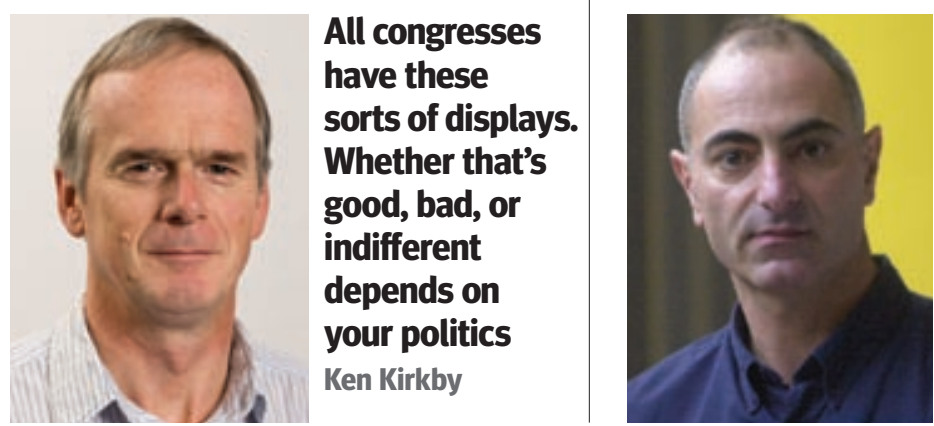

\section{We are well remunerated and can afford to pay for our own education} Jon Jureidini

New Zealand College of Psychiatrists. Kirkby strongly rejects the claim that the college doesn't want to offend industry and says there is an "arm's length" relationship with congress sponsors. He says the college is "in no position to make a decision in favour" of the proposal to wind back industry sponsorship, as it "needs to be carefully considered." Conceding there are "broader social concerns" about the profession's relationship with industry, he told the $B M J$ that in addition to its education and ethics committees examining the issue, the royal college had also asked a third body, its board of professional-community relations, to advise it on the question of sponsorship.

"We're reviewing our sponsorship policy, including our relationship with industry," says Kirkby, a professor of psychiatry at the University of Tasmania, adding that the issues are reviewed regularly by the college. Asked about his personal reaction to the giant drug displays that dominate his college's flagship educational event, Kirkby said “It doesn't register a great deal-all congresses have these sorts of displays. Whether that's good, bad, or indifferent depends on your politics. Sponsorship is a major support for this activity."

Sponsorship of educational events takes several forms, some more overt than others, making it difficult to know exactly what proportion of the total funding comes from pharmaceutical companies. Along with direct "naming rights," there is renting of exhibition space, registration fees of the many drug company salespeople who attend, and companies subsidising the costs of individual psychiatrists by paying their registration fees or helping with travel and accommodation. In the case of the Australian congress, according to the college president the total costs are between $\mathrm{A} \$ 2 \mathrm{~m}(£ 970000 ; € 1.2 \mathrm{~m} ; \$ 1.75 \mathrm{~m})$ and A $\$ 3 \mathrm{~m}$, with up to $10 \%$ covered by sponsorship from naming rights, and about another $10 \%$ from the renting of exhibition space.

\section{Is it over?}

Whatever happens with the flagship educational events like the annual congress, and whether or not Suzanne Fletcher's five year phase-out is widely adopted, a small group of hospital based psychiatrists in Adelaide have decided to institute their own ban on sponsorship, effective immediately. When Battersby was meeting with his dozen or so psychiatrist colleagues at the Flinders Medical Centre recently, the subject of sponsorship came up. A drug company had offered to send a visiting "key opinion leader" to the hospital to deliver an "educational" presentation about a drug. Without Battersby saying much, a discussion about sponsored education ensued, and the group ultimately decided to end all drug company sponsorship of psychiatric educational activities at their hospital. In mid-July, at a third meeting on the issue, the Flinders Medical Centre's department of psychiatry agreed on the new policy. The frequency of the psychiatrists' free lunches might decline, but the hope is there may be a commensurate reduction in the risk of irrational or inappropriate prescribing.

Ray Moynihan is visiting editor, $B M$ J, and conjoint lecturer, University of Newcastle

Ray.moynihan@newcastle.edu.au

Competing interests: None declared.

1 Moynihan R, Cassels A. Selling sickness: how drug companies are turning us all into patients. Sydney: Allen and Unwin, 2005.

2 Sorrell WH. Pharmaceutical marketing disclosures. publication date needed www.atg.state.vt.us/ upload/1215544954_2008_Pharmaceutical Marketing_Disclosures_Report.pdf

3 Moynihan R, Robertson J, Walkom E, Bero L, Henry D. A descriptive analysis of the world's first comprehensive disclosure of pharmaceutical industry funded events for health professionals. Submitted to BMJ.

4 Fletcher S. Continuing education in the health professions: improving healthcare through lifelong learning. Chairman's summary of the conference. Josiah MacyJrFoundation, 2008. www.josiahmacyfoundation. org/documents/Macy_ContEd 17 08.pdf

5 Steinman MA, Bero LA, Chren M-M, Landefeld S. The promotion of Gabapentin: an analysis of internal industry documents. Ann Intern Med 2006;145:284-93.

6 Wazana A. Physicians and the pharmaceutical industry: is a gift ever just a gift? JAMA 2000;283:373-80.

7 American Association of Medical Colleges Task Force. Industry funding of medical education. 2008 https://services.aamc.org/Publications/ index.cfm?fuseaction=Product.displayForm\&prd id $=232 \&$ prv_id $=281$.

Cite this as: BMJ 2008;337: a925

See EDITORIAL p 469, ANALYSIS p 490 